\title{
Commonly used preparations for colonoscopy: Efficacy, tolerability and safety - A Canadian Association of Gastroenterology position paper
}

\author{
Alan Barkun $\mathrm{MD}^{1,2}$, Naoki Chiba MD MSc${ }^{3,4}$, Robert Enns $\mathrm{MD}^{5}$, Margaret Marcon MD ${ }^{6}$, \\ Susan Natsheh MD${ }^{7}$, Co Pham PharmD ${ }^{8}$, Dan Sadowski MD ${ }^{9}$, Stephen Vanner MD ${ }^{10}$
}

\begin{abstract}
A Barkun, N Chiba, R Enns, et al. Commonly used preparations for colonoscopy: Efficacy, tolerability and safety A Canadian Association of Gastroenterology position paper. Can J Gastroenterol 2006;20(11):699-710.
\end{abstract}

INTRODUCTION: The increased demand for colonoscopy, coupled with the introduction of new bowel cleansing preparations and recent caution advisories in Canada, has prompted a review of bowel preparations by the Canadian Association of Gastroenterology.

METHODS: The present review was conducted by the Clinical Affairs group of committees including the endoscopy, hepatobiliary/transplant, liaison, pediatrics, practice affairs and regional representation committees, along with the assistance of Canadian experts in the field. An effort was made to systematically assess randomized prospective trials evaluating commonly used bowel cleansing preparations in Canada.

RESULTS: Polyethylene glycol (PEG)-; sodium phosphate (NaP)-; magnesium citrate (Mg-citrate)-; and sodium picosulphate, citric acid and magnesium oxide (PSMC)-containing preparations were reviewed. Regimens of PEG $2 \mathrm{~L}$ with bisacodyl $(10 \mathrm{mg}$ to $20 \mathrm{mg}$ ) or Mg-citrate $(296 \mathrm{~mL}$ ) are as effective as standard PEG $4 \mathrm{~L}$ regimens, but are better tolerated. $\mathrm{NaP}$ preparations appear more effective and better tolerated than standard PEG solutions. PSMC has good efficacy and tolerability but head-to-head trials with $\mathrm{NaP}$ solutions remain few, and conclusions equivocal. Adequate hydration during preparation and up to the time of colonoscopy is critical in minimizing side effects and improving bowel cleansing in patients receiving $\mathrm{NaP}$ and PSMC preparations. All preparations may cause adverse events, including rare, serious outcomes. $\mathrm{NaP}$ should not be used in patients with cardiac or renal dysfunction (PEG solution is preferable in these patients), bowel obstruction or ascites, and caution should be exercised when used in patients with preexisting electrolyte disturbances, those taking medications that may affect electrolyte levels and elderly or debilitated patients. Health Canada's recommended $\mathrm{NaP}$ dosing for most patients is two $45 \mathrm{~mL}$ doses $24 \mathrm{~h}$ apart. However, both safety and efficacy data on this dosing schedule are lacking. Many members of the Canadian Association of Gastroenterology expert panel administer both doses within $24 \mathrm{~h}$, as studied in clinical trials, after careful one-on-one discussion of risks and benefits in carefully selected patients. Safety data on PSMC and combination preparations in North America are limited and clinicians are encouraged to keep abreast of developments in this area.

CONCLUSIONS: All four preparations reviewed provided effective bowel cleansing for colonoscopy in the majority of patients, with varying tolerability. Adequate hydration is essential in patients receiving the preparations.

Key Words: Colon preparation; Colonoscopy; Polyethylene glycol; Sodium phosphate

\section{L'efficacité, la tolérabilité et l'innocuité de préparations de coloscopie courantes : Un document de principes de l'Association canadienne de gastroentérologie}

\begin{abstract}
INTRODUCTION : La demande accrue de coloscopies, couplée à l'apparition de nouvelles préparations intestinales et de récentes mises en garde au Canada, a incité l'Association canadienne de gastroentérologie à analyser les préparations intestinales.

MÉTHODOLOGIE : Le groupe des comités des affaires cliniques a procédé à la présente analyse, y compris les comités sur l'endoscopie, les troubles hépatobiliaires et les greffes, les représentants, la pédiatrie, les affaires de pratique et les représentants régionaux, avec l'aide d'experts canadiens dans le domaine. On s'est efforcé d'évaluer systématiquement les essais aléatoires et prospectifs sur les principales préparations intestinales au Canada.
\end{abstract}

RÉSULTATS : Les préparations contenant du polyéthylène-glycol (PEG), du phosphate de sodium ( $\mathrm{NaP})$, ainsi que du citrate de magnésium, du picosulfate sodique, de l'acide citrique et de l'hydroxyde de magnésium (PSMC), ont été analysées. Les posologies de 2 litres de PEG conjuguées à du bisacodyl $(10 \mathrm{mg}$ à $20 \mathrm{mg})$ ou à du citrate de magnésium $(296 \mathrm{~mL})$ sont aussi efficaces qu'une posologie standard de 4 litres de PEG, mais mieux tolérées. Les préparations de $\mathrm{NaP}$ semblent plus efficaces et mieux tolérées que les solutions de PEG standard. Les préparations de PSMC affichent une bonne efficacité et une bonne tolérabilité, mais les essais par rapport aux solutions de $\mathrm{NaP}$ sont rares, et les conclusions sont équivoques. Il est essentiel d'assurer une hydratation suffisante entre la préparation et à la coloscopie pour réduire les effets secondaires au minimum et améliorer la purge intestinale des patients qui reçoivent des préparations de $\mathrm{NaP}$ et de PSMC. Toutes les préparations peuvent s'associer à des effets indésirables, y compris des issues rares et graves. Le NaP ne devrait pas être utilisé chez les patients atteints d'un dysfonctionnement cardiaque ou rénal (la solution de PEG est alors préférable), d'occlusion intestinale ou d'asciites, et il faut les utiliser avec prudence chez les patients ayant déjà des troubles électrolytiques, qui prennent des médicaments susceptibles de nuire aux taux d'électrolytes ou qui sont âgés ou atteints de maladies débilitantes. Pour la plupart des patients, Santé Canada recommande d'administrer deux doses de $45 \mathrm{~mL}$ à 24 heures d'intervalle. Cependant, il n'existe pas de données d'innocuité et d'efficacité sur un tel mode d'administration. De nombreux membres du comité d'experts de l'Association canadienne de gastroentérologie administrent les deux doses en 24 heures, conformément aux essais cliniques, après avoir procédé à une évaluation attentive des risques et des bienfaits auprès de patients soigneusement sélectionnés. Les données d'innocuité sur le PSMC et les préparations combinées sont limitées en Amérique du Nord, et les cliniciens sont invités à se tenir au courant de l'évolution de ce domaine.

CONCLUSIONS : Les quatre préparations analysées assuraient un nettoyage intestinal efficace pour la coloscopie chez la majorité des patients et s'associaient à une tolérabilité variable. Il est essentiel de fournir une hydratation efficace aux patients qui reçoivent les préparations.

${ }^{1}$ Division of Gastroenterology, McGill University Health Centre; ${ }^{2}$ Department of Clinical Epidemiology, McGill University, Montreal, Quebec;

${ }^{3}$ Division of Gastroenterology, McMaster University, Hamilton, Ontario; ${ }^{4}$ Surrey GI Research Inc, Guelph, Ontario; ${ }^{5}$ Division of

Gastroenterology, University of British Columbia, Vancouver, British Columbia; ${ }^{6}$ Division of Gastroenterology, The Hospital for Sick Children,

University of Toronto, Toronto, Ontario; ${ }^{7}$ Department of Pediatrics, Saint John Regional Hospital, Saint John, New Brunswick; ${ }^{8}$ Faculty of

Pharmacy, McGill University Health Centre, University of Montreal, Montreal, Quebec; ${ }^{9}$ Division of Gastroenterology, Royal Alexandra

Hospital, Edmonton, Alberta; ${ }^{10}$ Hotel Dieu Hospital, Kingston, Ontario

Correspondence: Mr Paul Sinclair, The Canadian Association of Gastroenterology, 2902 South Sheridan Way, Suite 201, Oakville,

Ontario L6J 7L6. Telephone 905-829-2504, fax 905-829-0242, e-mail cagoffice@cag-acg.org

Received and accepted for publication August 29, 2006 
In Canada, colorectal cancer is the second most common cause of cancer-related death (1). In addition to its use in screening for and managing colorectal cancer, colonoscopy is used to assess gastrointestinal or rectal bleeding, abdominal pain, anemia, irritable or inflammatory bowel symptoms, and other gastrointestinal signs and symptoms $(2,3)$.

Adequate colon preparation is required for successful visualization of the colon, and essential for the detection of suspicious lesions. However, studies using large databases reveal that up to $23 \%$ of all colonoscopies have suboptimal bowel preparation (4) resulting in lower cecal intubation rates (5), longer procedural times (6) and decreased polyp detection $(4,6)$. Inadequate preparation may lead to incomplete visualization of the colon, resulting in shortened screening intervals due to concerns about missed lesions (7). This will further increase the demand and waiting times for colonoscopy.

There are many reasons for an inadequate colonic preparation. Poor compliance due to incomplete consumption of the colon preparation is a strong influence (8), with excess bowel preparation volume cited as the most common deterrent to colonoscopy (9). Preparations must be selected based on optimal efficacy and tolerability while also remaining safe.

The increased demand for colonoscopy, attributable to widespread colorectal cancer screening and surveillance, coupled with the introduction of new bowel cleansing preparations and recent caution advisories in Canada, has prompted a review of bowel preparations by the Canadian Association of Gastroenterology (CAG). The present review was conducted by the Clinical Affairs group of committees including the endoscopy, hepatobiliary/transplant, liaison, pediatrics, practice affairs and regional representation committees, along with the assistance of Canadian experts in the field. The reader is also referred to a recent multisociety American publication (10) on the present topic.

\section{OVERVIEW OF BOWEL CLEANSING PREPARATIONS}

Adequate bowel cleansing may be achieved through a variety of mechanisms. Recommendations for diet and hydration vary from centre to centre and will not be discussed in the present review. Commonly used bowel cleansing preparations in Canada include polyethylene glycol (PEG)-; sodium phosphate (NaP)-; magnesium citrate (Mg-citrate)-; and sodium picosulphate, citric acid and magnesium oxide (PSMC)-containing preparations.

The mechanism of action of these compounds has an impact on the choice of preparations in patients with comorbidities (see Safety section). PEG-containing preparations (eg, GoLYTELY, Braintree Laboratories Inc, Canada; Colyte, Zymcan Pharmaceuticals Inc, Canada; Peglyte, Pharmascience Inc, Canada and Klean-Prep, Rivex Pharma Inc, Canada) are large-volume, osmotically balanced solutions that act as purgatives to evacuate the intestine through the ingestion of nonabsorbable fluid.

NaP-based preparations (eg, Fleet Phospho-Soda, Johnson \& Johnson - Merck Consumer Pharmaceuticals of Canada and Enemol, Dominion Pharmacal, Canada) are small-volume, hyperosmotic solutions that exert their purgative action through osmotically drawing fluid into the intestinal lumen. PSMC (Pico-Salax, Ferring Pharmaceuticals Inc, Canada) contains sodium picosulphate (which decreases water and electrolyte absorption, as well as increases motility) and Mg-citrate (an osmotic laxative).
Mg-citrate (eg, Citro-Mag, Rougier Pharma, Canada) is a hyperosmolar laxative that also exerts its effect by enhancing intestinal peristalsis and stimulating the release of cholecystokinin (11) to cause secretory diarrhea. Historically, Mg-citrate was mainly used in preparations for radiological imaging tests of the colon.

Sample costs for these bowel preparations are shown in Table 1 . These costs may vary depending on the location and pharmacy where they are purchased. However, the costeffectiveness of bowel preparations should reflect the cost of re-examination as a result of inadequate bowel preparation if that is an issue with a particular preparation $(7,9)$.

\section{EFFICACY AND TOLERABILITY}

The literature on colon preparations includes studies of varying degrees of quality, with disparate definitions of validated and nonvalidated tools of outcome measurement, and varying patient populations and preparation protocols. The present review includes primarily randomized controlled trials (RCTs) that assess the efficacy and tolerability of the four types of preparations in patients undergoing colonoscopy. Studies assessing bowel preparations for barium enema were not included because the efficacy implications may be quite different. Many of the trials compare two or more bowel preparations; therefore, some repetition in the sections for the different preparations was necessary to allow easy access to information.

\section{PEG}

PEG has been available since 1980 and its efficacy was established compared with older diet and cathartic regimens (12,13). Sixteen trials (14-29) compared PEG with $\mathrm{NaP}$ (Table 2). NaP was superior to PEG in efficacy in six of 16 trials, and was superior in tolerability and acceptability in seven of 16 trials. Only two trials $(29,30)$ suggested that PEG was superior to $\mathrm{NaP}$ with regards to efficacy. Even after bisacodyl was added to PEG, NaP continued to be more effective and better tolerated (31). In general, more patients receiving $\mathrm{NaP}$ than PEG were willing to repeat the preparation $(17-19,32)$, while those who had previously used PEG expressed a preference for using $\mathrm{NaP}$ in the future $(14,22)$.

In separate trials, PEG was no more effective than bisacodyl or senna, with no differences in tolerability and acceptability (Table 3) $(33,34)$.

More studies (33-46) have focused on ways to increase the efficacy and patient tolerability and acceptability of PEG (Table 3). The addition of bisacodyl, senna or Mg-citrate to PEG increased the efficacy compared with PEG alone, without decreasing tolerability and acceptability (35-37). Although PEG is generally well tolerated, $5 \%$ to $38 \%$ of patients do not complete the preparation because of poor palatability or large volume $(16,18,38)$. Use of low-volume PEG $2 \mathrm{~L}$ in combination with Mg-citrate (39), bisacodyl (39-42) or senna (38) was generally better tolerated than PEG $4 \mathrm{~L}$, but efficacy varied (Table 3). PEG 2 L plus bisacodyl (10 $\mathrm{mg}$ to $20 \mathrm{mg}$ ) or Mg-citrate

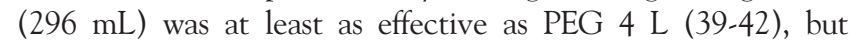
PEG $2 \mathrm{~L}$ plus senna was not (38). Use of PEG 1.5 L or $2 \mathrm{~L}$ with PSMC was equally or less effective than PEG $4 \mathrm{~L}$, but with no improvement in tolerability and acceptability $(43,44)$. Two studies $(45,46)$ found that administering PEG $4 \mathrm{~L}$ or $3 \mathrm{~L}$ (with or without bisacodyl) in divided doses, reduced the need for dietary restrictions, improved efficacy, and in one study (46) improved tolerability and acceptability. Despite these limitations, PEG is 
TABLE 1

Relative cost of bowel cleansing preparations

\begin{tabular}{|c|c|c|c|c|}
\hline Preparation & Product & Hospital cost & Retail cost & Suggested retail price \\
\hline Magnesium citrate & Citro-Mag* $(300$ mL) & $\$ 1.55$ & $\$ 2.44$ & $\$ 4.79$ \\
\hline Sodium phosphate & Fleet Phospho-Soda ${ }^{\dagger}(45 \mathrm{~mL})$ & $\$ 2.69 \times 2=\$ 5.38$ & $\$ 3.77 \times 2=\$ 7.54$ & $\$ 6.99 \times 2=\$ 13.98$ \\
\hline Polyethylene glycol & GoLYTELY‡ (4 L) & $\$ 12.30$ & $\$ 14.55$ & $\$ 25.49$ \\
\hline $\begin{array}{l}\text { Sodium picosulphate, citric acid } \\
\text { and magnesium oxide }\end{array}$ & Pico-Salax§ (two sachets) & $\$ 12.60$ & $\$ 12.69$ & $\$ 22.99$ \\
\hline
\end{tabular}

Hospital costs are based on the Sir Mortimer B Davis - Jewish General Hospital and McGill University Health Centre, Montreal, Quebec. Retail costs and suggested retail prices are based on the distribution centre of Shoppers Drug Mart Canada. *Rougier Pharma, Canada; †Johnson \& Johnson - Merck Consumer Pharmaceuticals of Canada; ${ }^{\ddagger}$ Braintree Laboratories Inc, Canada; §Ferring Pharmaceuticals Inc, Canada

TABLE 2

Randomized comparisons of sodium phosphate (NaP) versus polyethylene glycol (PEG) bowel preparations for colonoscopy

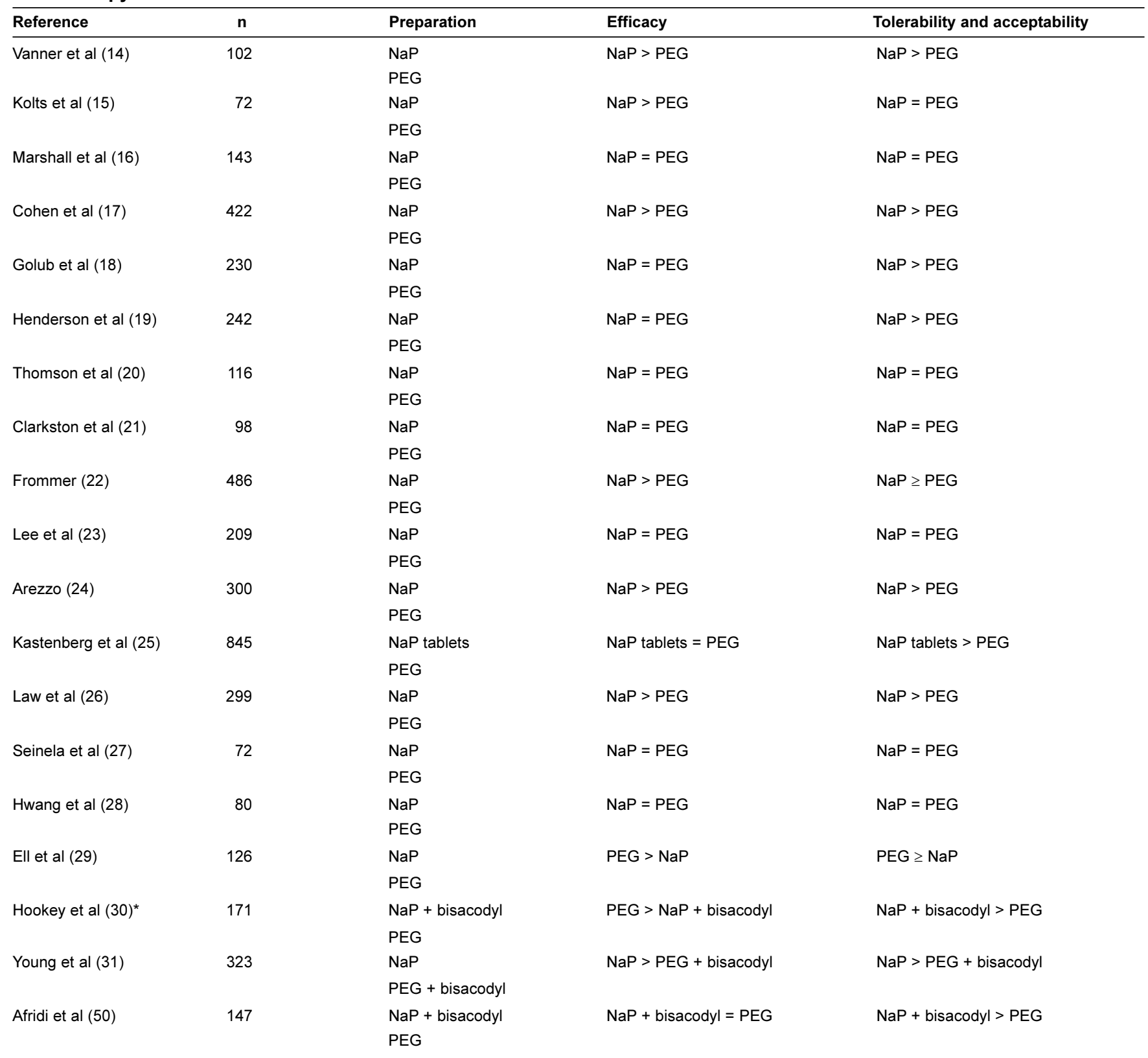

*Low dose $(1 \times 45 \mathrm{~mL})$ of $\mathrm{NaP}$ 
TABLE 3

Randomized comparisons of various administration strategies of polyethylene glycol (PEG) bowel preparations for colonoscopy

\begin{tabular}{|c|c|c|c|c|}
\hline Reference & $\mathbf{n}$ & Preparation & Efficacy & Tolerability and acceptability \\
\hline \multirow[t]{2}{*}{ Wang and Lin (33) } & 104 & PEG & PEG = bisacodyl & PEG = bisacodyl \\
\hline & & Bisacodyl & & \\
\hline \multirow[t]{2}{*}{ Radaelli et al (34) } & 283 & PEG & Senna $>$ PEG & Senna $=$ PEG \\
\hline & & Senna & & \\
\hline \multirow[t]{2}{*}{ Clarkston and Smith (35) } & 114 & PEG & PEG + bisacodyl > PEG & PEG = PEG + bisacodyl \\
\hline & & PEG + bisacodyl & & \\
\hline \multirow[t]{2}{*}{ Ziegenhagen et al (36) } & 120 & PEG & $P E G$ + senna > PEG & $P E G=P E G+$ senna \\
\hline & & PEG + senna & & \\
\hline \multirow[t]{2}{*}{ Sharma et al (37) } & 80 & PEG + Mg-citrate & PEG + Mg-citrate > PEG & PEG + Mg-citrate > PEG \\
\hline & & PEG & & \\
\hline \multirow[t]{2}{*}{ Hookey et al (38) } & 171 & PEG 4 L & PEG $4 \mathrm{~L}>$ PEG $2 \mathrm{~L}$ + senna & PEG $2 \mathrm{~L}$ + senna > PEG $4 \mathrm{~L}$ \\
\hline & & PEG 2 L + senna & & \\
\hline \multirow[t]{3}{*}{ Sharma et al (39) } & 150 & PEG $4 \mathrm{~L}$ & PEG 2 L + Mg-citrate, & PEG $2 \mathrm{~L}+$ Mg-citrate > PEG $2 \mathrm{~L}$ \\
\hline & & PEG 2 L + Mg-citrate & PEG 2 L + bisacodyl > PEG 4 L & + bisacodyl $\geq$ PEG $4 \mathrm{~L}$ \\
\hline & & PEG 2 L + bisacodyl & & \\
\hline \multirow[t]{2}{*}{ Adams et al (40) } & 382 & PEG $4 \mathrm{~L}$ & PEG $2 \mathrm{~L}+$ bisacodyl = PEG $4 \mathrm{~L}$ & PEG $2 \mathrm{~L}+$ bisacodyl = PEG $4 \mathrm{~L}$ \\
\hline & & PEG 2 L + bisacodyl & & \\
\hline \multirow[t]{2}{*}{ DiPalma et al (41) } & 200 & PEG $4 \mathrm{~L}$ & PEG $2 \mathrm{~L}+$ bisacodyl = PEG $4 \mathrm{~L}$ & PEG $2 \mathrm{~L}+$ bisacodyl > PEG $4 \mathrm{~L}$ \\
\hline & & PEG 2 L + bisacodyl & & \\
\hline \multirow[t]{3}{*}{ Huppertz-Hauss et al (42) } & 231 & PEG $4 \mathrm{~L}$ & $\mathrm{NaP}=\mathrm{PEG} 2 \mathrm{~L}+$ bisacodyl $=$ & $\mathrm{NaP}=\mathrm{PEG} 2 \mathrm{~L}+$ bisacodyl $=\mathrm{PEG} 4 \mathrm{~L}$ \\
\hline & & PEG 2 L + bisacodyl & PEG $4 \mathrm{~L}$ & \\
\hline & & $\mathrm{NaP}$ & & \\
\hline \multirow[t]{3}{*}{ Hangartner et al (43) } & 300 & PEG $4 \mathrm{~L}$ & PEG 4 L > senna + enema > & Senna + enema > PEG 4 L, PEG 2 L + \\
\hline & & PEG 2 L + PSMC & PEG 2 L + PSMC & PSMC \\
\hline & & Senna + enema & & \\
\hline \multirow[t]{2}{*}{ Borkje et al (44) } & 183 & PEG $4 \mathrm{~L}$ & PEG $4 \mathrm{~L}=$ PEG $1.5 \mathrm{~L}+\mathrm{PSMC}$ & PEG $4 \mathrm{~L}=$ PEG $1.5 \mathrm{~L}+\mathrm{PSMC}$ \\
\hline & & PEG 1.5 L + PSMC & & \\
\hline \multirow[t]{2}{*}{ Aoun et al (45) } & 141 & PEG 4 L + liquid diet & PEG $2 \mathrm{~L}(\times 2)+$ regular diet $>$ PEG $4 \mathrm{~L}$ & PEG $2 \mathrm{~L}(\times 2)+$ regular diet $=$ PEG $4 \mathrm{~L}+$ \\
\hline & & PEG $2 \mathrm{~L}(\times 2)+$ regular diet & + liquid diet & liquid diet \\
\hline \multirow[t]{2}{*}{ El Sayed et al (46) } & 187 & PEG $3 \mathrm{~L}+$ liquid diet & PEG $2 \mathrm{~L}$ + bisacodyl + regular diet + & PEG 2 L + bisacodyl + regular diet + \\
\hline & & PEG 2 L + bisacodyl + & PEG 1 L > PEG 3 L + liquid diet & PEG 1 L > PEG 3 L + liquid diet \\
\hline
\end{tabular}

Mg-citrate Magnesium citrate; NaP Sodium phosphate; PSMC Sodium picosulphate plus Mg-citrate

an iso-osmotic solution and is preferred in patients with significant cardiac or renal disease.

\section{$\mathrm{NaP}$}

As mentioned above, sixteen trials (14-29) compared PEG with $\mathrm{NaP}$ (Table 2). NaP was superior to PEG in efficacy in six of 16 trials, and was superior in tolerability and acceptability in seven of 16 trials. Only two trials $(29,30)$ suggested that PEG was superior to $\mathrm{NaP}$ with regards to efficacy. $\mathrm{NaP}$ was more effective and equally tolerated compared with PSMC in two studies $(47,48)$, while in a third study, the two preparations were equally effective but PSMC was better tolerated (Table 4) (49).

Bisacodyl did not appear to increase the efficacy of $\mathrm{NaP}-$ the combination was equal to or less effective than PEG $(30,50)$ but the combination of bisacodyl and $\mathrm{NaP}$ was better tolerated than PEG. The ingestion of a carbohydrate-electrolyte solution (Gatorade, PepsiCo Inc, USA or E-lyte, BodyBio Inc, USA) to counteract the fluid and electrolyte shifts of $\mathrm{NaP}$ further increased efficacy and either improved or did not affect tolerability and acceptability compared with $\mathrm{NaP}$ alone (Table 5 )
$(51,52)$. The addition of the carbohydrate-electrolyte solution resulted in less intravascular volume contraction, hypokalemia and the need for intravenous rehydration. In one study (53), using $\mathrm{NaP}$ with a liberalized diet (light lunch after a light breakfast) was equally effective and tolerated compared with $\mathrm{NaP}$ plus a clear liquid diet. However, no study to date has determined whether a regular breakfast may be allowed.

Strategies for additional preparation in the case of inadequate bowel cleansing may vary from centre to centre. However, clinicians are cautioned not to use higher than the standard $\mathrm{NaP}$ dosing regimens in patients with an initial poor preparation.

\section{PSMC}

In terms of efficacy, PSMC was more effective (11), less effective (54) and equivalent to (55) PEG in three controlled trials (Table 4). PSMC was better tolerated in all three trials (Table 4). Two of three trials $(47,48)$ demonstrated superior efficacy of $\mathrm{NaP}$ over PSMC with no difference in tolerability and acceptability, while in the third trial (49) that used a higher 
TABLE 4

Randomized comparisons of sodium picosulphate plus magnesium citrate (PSMC) bowel preparations for colonoscopy

\begin{tabular}{|c|c|c|c|c|}
\hline Reference & $\mathbf{n}$ & Preparation & Efficacy & Tolerability and acceptability \\
\hline \multirow[t]{2}{*}{ Regev et al (11) } & 68 & PSMC & PSMC > PEG & PSMC > PEG \\
\hline & & PEG & & \\
\hline \multirow[t]{2}{*}{ Chilton et al (32) } & 132 & PEG 1 L + PSMC + senna & PEG $1 \mathrm{~L}+$ PSMC + senna $>\mathrm{NaP}$ & Not reported \\
\hline & & $\mathrm{NaP}$ & & \\
\hline \multirow[t]{2}{*}{ Hangartner et al (43) } & 300 & PEG 2 L + PSMC & PEG 4 L > senna + enema > & Senna + enema > PEG 4 L, \\
\hline & & PEG $4 \mathrm{~L}$ & PEG 2 L + PSMC & PEG 2 L + PSMC \\
\hline Borkje et al (44) & & PEG $4 \mathrm{~L}$ & & \\
\hline \multirow[t]{2}{*}{ Yoshioka et al (47) } & 103 & PSMC & $\mathrm{NaP}>\mathrm{PSMC}$ & $\mathrm{PSMC}=\mathrm{NaP}$ \\
\hline & & $\mathrm{NaP}$ & & \\
\hline \multirow[t]{2}{*}{ Tjandra et al (48) } & 225 & PSMC & $\mathrm{NaP}>\mathrm{PSMC}$ & $\mathrm{PSMC}=\mathrm{NaP}$ \\
\hline & & $\mathrm{NaP}$ & & \\
\hline Dakkak et al (54) & & PEG & & \\
\hline \multirow[t]{2}{*}{ Hamilton et al (55) } & 55 & PSMC & $P S M C=P E G$ & PSMC > PEG \\
\hline & & PEG & & \\
\hline
\end{tabular}

*High dose (three sachets) of PSMC. NaP Sodium phosphate; PEG Polyethylene glycol

TABLE 5

Randomized comparisons of the use of carbohydrate-electrolyte (carb/electrolye) solutions or diets with sodium phosphate (NaP) bowel preparations for colonoscopy

\begin{tabular}{lcll}
\hline Reference & $\mathbf{n}$ & Preparation & Efficacy \\
\hline Barclay et al (51) & 168 & $\mathrm{NaP}$ & $\mathrm{NaP}+$ carb/electrolyte $>\mathrm{NaP}$ \\
Tjandra and Tagkalidis (52) & 187 & $\mathrm{NaP}+$ carb/electrolyte & $\mathrm{NaP}+$ carb/electrolyte $>\mathrm{NaP}$ \\
Scott et al (53) & 200 & $\mathrm{NaP}+$ carb/electrolyte & $\mathrm{NaP}$ \\
& & $\mathrm{NaP}+$ diet liberalization & $\mathrm{NaP}=\mathrm{NaP}+$ diet liberalization
\end{tabular}

Carb/electrolyte solutions were Gatorade (PepsiCo Inc, USA) or E-lyte (BodyBio Inc, USA)

dosage of PSMC, the two preparations were equally effective but PSMC was better tolerated (Table 4). When PSMC was used in combination with low-volume PEG (1.5 L or $2 \mathrm{~L})$, the combination was equally or less effective than PEG $4 \mathrm{~L}$ with no improvement in tolerability and acceptability $(43,44)$. A lowdose, low-volume triple regimen of PSMC, PEG $1 \mathrm{~L}$ and senna was more effective than $\mathrm{NaP}$ (32). The clinical experience of many of the CAG committee members suggests that the amount of fluid intake is critical to the quality of preparation with PSMC.

\section{Mg-citrate}

In patients undergoing colonoscopy, Mg-citrate and bisacodyl was more effective and better tolerated than castor oil (Table 6) (56). When used alone or in combination with bisacodyl and a diet kit, Mg-citrate was as or more effective than $\mathrm{NaP}(57,58)$, but tolerability and acceptability were greater only with the combination of Mg-citrate, bisacodyl and a diet kit. As in studies with PEG $(45,46)$, and NaP $(53)$, it may be possible to relax the need for dietary restrictions. A low-residue diet kit combining $\mathrm{Mg}$-citrate and bisacodyl was more effective and better tolerated than $\mathrm{NaP}$ with a standard clear liquid diet (58). Mg-citrate added to a low-volume PEG preparation improved patient tolerability without sacrificing efficacy of colon cleansing compared with the standard PEG 4 L $(37,39)$.

\section{SAFETY}

All bowel preparations may cause adverse events. The clinician must be aware of the patient's comorbidities and be familiar with the adverse events profile and recommended modes of administration when selecting a preparation.

A review of $\mathrm{NaP}$ and PEG studies conducted in 2002 assessed the rate of adverse events reported to major government institutions (59). Between 1997 and 2002, the United States Food and Drug Administration (FDA) received 100 reports of adverse events with PEG solutions, including 30 serious and six fatal events (59). Between the same time period, the United States FDA received 34 adverse event reports related to oral $\mathrm{NaP}$ solutions, 18 of which were serious events, including eight fatalities (59). A review of published case reports (59) suggested that definite or probable predisposing factors were identifiable in 10 of 13 patients with severe adverse events. However, three patients had no identifiable predisposing factors. In all identifiable 


\section{TABLE 6}

Randomized comparisons of magnesium citrate (Mg-citrate) bowel preparations for colonoscopy

\begin{tabular}{|c|c|c|c|c|}
\hline Reference & $\mathbf{n}$ & Preparation & Efficacy & Tolerability and acceptability \\
\hline \multirow[t]{2}{*}{ Sharma et al (37) } & 80 & Mg-citrate + PEG & Mg-citrate + PEG > PEG & Mg-citrate + PEG > PEG \\
\hline & & PEG & & \\
\hline \multirow[t]{3}{*}{ Sharma et al (39) } & 150 & PEG 4 L & PEG 2 L + Mg-citrate, & PEG 2 L + Mg-citrate > \\
\hline & & PEG 2 L + Mg-citrate & PEG $2 \mathrm{~L}+$ bisacodyl > PEG $4 \mathrm{~L}$ & PEG $2 \mathrm{~L}+$ bisacodyl $\geq$ PEG $4 \mathrm{~L}$ \\
\hline & & PEG 2 L + bisacodyl & & \\
\hline \multirow[t]{2}{*}{ Chen et al (56) } & 70 & Mg-citrate + bisacodyl & Mg-citrate + bisacodyl $>$ castor oil & Mg-citrate + bisacodyl $>$ castor oil \\
\hline & & Castor oil & & \\
\hline \multirow[t]{2}{*}{ Berkelhammer et al (57) } & 297 & Mg-citrate & Mg-citrate $\geq \mathrm{NaP}$ & $\mathrm{NaP}>\mathrm{Mg}$-citrate \\
\hline & & $\mathrm{NaP}$ & & \\
\hline \multirow[t]{3}{*}{ Delegge and Kaplan (58) } & 506 & Mg-citrate + bisacodyl + & Mg-citrate + bisacodyl + diet kit $>$ & Mg-citrate + bisacodyl + \\
\hline & & diet kit & $\mathrm{NaP}+$ liquid diet & diet kit > NaP + liquid diet \\
\hline & & $\mathrm{NaP}+$ liquid diet & & \\
\hline
\end{tabular}

NaP Sodium phosphate; PEG Polyethylene glycol

serious adverse events, inappropriate dosing, inappropriate patient selection or inadequate hydration could be identified as predisposing factors.

Spontaneous adverse reactions reported to the Canadian Adverse Drug Reaction Monitoring Program as of September 2005 included 38 reports with oral NaP, 18 reports with PEG, 31 reports with Mg-citrate and one report with PSMC (60), keeping in mind that PSMC has only been made available in Canada since 2005. From May 1997 to October 2001, Health Canada received 10 reports of suspected adverse reactions to oral $\mathrm{NaP}$, nine of which were serious and none were fatal (61). Five patients had electrolyte disturbances, including hypocalcemia and hyperphosphatemia, four of whom had a medical history of renal insufficiency, cardiovascular disease or concomitant use of medications that affected electrolytes. At least four of the 10 patients ingested more than $45 \mathrm{~mL}$ of $\mathrm{NaP}$ within a $24 \mathrm{~h}$ period.

Because of concerns with the $\mathrm{NaP}$ preparation, both the United States FDA and Health Canada recommended a 'black box advisory' against the use of more than $45 \mathrm{~mL}$ of oral $\mathrm{NaP}$ within $24 \mathrm{~h}(62)$. However, experience from clinical trials where $90 \mathrm{~mL}$ of $\mathrm{NaP}$ was used within $24 \mathrm{~h}$ suggests that this dosing may be suitable in some cases; in fact, many members of the CAG expert panel administer this dosing schedule after careful one-on-one discussion of risks and benefits in carefully selected patients.

There is more experience with PSMC in the United Kingdom, and between 1995 and 2001, Ferring Pharmaceuticals Ltd, United Kingdom, described 21 reported adverse events, including five serious events of hyponatremia and no fatalities (63). In addition, in 2002, the Australian Adverse Drug Reactions Advisory Committee described 16 reports of serious adverse events with PSMC with no fatalities (64).

\section{PEG}

As with any oral preparation, PEG is contraindicated in patients with ileus, gastric retention, bowel perforation, gastrointestinal obstruction or severe colitis (65). Due to its iso-osmolarity, PEG appears to be relatively safe for patients with electrolyte imbalance and those who cannot tolerate a significant fluid load (renal failure, congestive heart failure [CHF] or advanced liver disease with ascites) (66).
In studies comparing PEG with $\mathrm{NaP}$, decreases in systolic blood pressure of over $10 \mathrm{mmHg}$ were noted in more patients treated with PEG in one study (45\% versus 28\%) (50) and fewer patients in another (7\% versus 16\%) (14); however, these differences were not statistically significant. In one study (50), a significantly higher number of patients experienced a $20 \mathrm{mmHg}$ drop in systolic blood pressure with PEG compared with $\mathrm{NaP}$ ( $25 \%$ versus $12 \%, \mathrm{P}=0.05$ ).

Rare adverse events reported with PEG include pulmonary aspiration, Mallory-Weiss tear, pancreatitis and colitis, cardiac dysrhythmia and inappropriate antidiuretic hormone syndrome (67-70). A mild, asymptomatic increase in plasma volume may occur (71), and one case of exacerbation of CHF in a patient with CHF and chronic renal insufficiency has been reported (72).

Three cases of serious dysnatremia were reported: one in a patient taking thiazide diuretics who presented with seizures and recovered, and two fatal cases in patients with end-stage renal disease (73).

PEG has not been shown to alter the histological features of the colonic mucosa and may be used in patients suspected of having inflammatory bowel disease (IBD) without interfering with the diagnosis (74).

\section{$\mathrm{NaP}$}

Because oral $\mathrm{NaP}$ may cause fluid and electrolyte shifts, it is contraindicated in patients with kidney disease or those on a sodium-restricted diet (65); it should not be used in patients with CHF or advanced liver disease $(8,59)$, and should be used with caution in elderly patients and patients with small intestinal disorders and with poor gut motility (8). As with any oral preparation, $\mathrm{NaP}$ should not be used in patients with bowel obstruction.

In a review of 26 studies (59), there were no major adverse events due to $\mathrm{NaP}$; however, it is important to note that patients with renal failure, ascites, serious heart disease and bowel obstruction were excluded from these trials. Most patients receiving $\mathrm{NaP}$ have transient hyperphosphatemia, more so in the elderly. Concerns have been expressed about a reciprocal decrease in serum calcium levels. The meta-analysis also reported on serum calcium levels in 654 patients in 12 trials (59). Most studies showed a small decrease in mean serum 
calcium levels, with a few cases below the normal calcium limit, but not in the range that would cause symptoms. Up to $20 \%$ of patients using $\mathrm{NaP}$ preparations developed hypokalemia $(59,75)$. Increases in sodium levels are generally small and do not lead to clinical sequelae (59); however, significant hyponatremia and seizures have been reported (76). Care must be taken in patients with a low seizure threshold and those with possible chronic sodium depletion, such as patients on thiazide diuretics.

In clinical trials, body weight, urine osmolality and serum sodium showed a trend toward minor intravascular volume contraction, but no correlation with symptoms attributable to the colonoscopy preparation was reported (59). The risk of clinically significant volume contraction and dehydration may be lessened by encouraging patients to drink clear fluids liberally during the days leading up to the procedure, especially during preparation (77).

In the meta-analysis (59), hemodynamic measurements were available from five studies, in 405 patients receiving $\mathrm{NaP}$. Decreases in blood pressure of over $10 \mathrm{mmHg}$ were noted in $16 \%$ to $28 \%$ of patients, and over $20 \mathrm{mmHg}$ in $12 \%$ to $16 \%$ of patients. Studies that compared NaP with PEG found no significant differences $(14,20,77)$ or a greater drop in blood pressure with PEG (50).

In December 2005, Health Canada issued an advisory regarding the safety of $\mathrm{NaP}$, due to concerns about nephrocalcinosis associated with renal failure (78). In addition to published reports of seven cases (79-81), an additional 30 cases of acute renal failure involving calcification of renal tissue have been spontaneously reported (78). Some of the cases appear to have involved inappropriate patient selection, as well as overdosing and $\mathrm{NaP}$ use in patients at higher risk of dehydration (eg, elderly and debilitated patients). In the published reports, six of seven patients were hypertensive, with five on an angiotensinconverting enzyme inhibitor or an angiotensin receptor blocker, and two also on diuretics. One patient had a relative contraindication (hyperparathyroidism) to the use of the product and another patient was given an overdose. A cohort study (82) suggested that the prevalence of the development of renal failure with $\mathrm{NaP}$ and PEG groups was similar (7\% versus 9\%, respectively), and that only age and blood pressure, independently, predicted renal failure regardless of the preparation used. Despite limitations, these data suggest that inadequate hydration, older age, hypertension and the use of diuretics and antihypertensives, and perhaps coronary artery disease may increase the risk of renal dysfunction in patients receiving $\mathrm{NaP}$ cleansing preparation, further emphasizing that precautions are required in these situations.

$\mathrm{NaP}$ has been shown to alter both the macroscopic and the microscopic features of the intestinal mucosa, and induce aphthoid erosions similar to those seen in IBD, thus confusing the colonoscopic appearance (83-86).

An anhydrous form of $\mathrm{NaP}$ sold as tablets in the United States remains unavailable in Canada.

\section{PSMC}

PSMC is contraindicated in patients with CHF, gastric retention, gastrointestinal ulceration, ileus, toxic colitis, gastrointestinal obstruction or perforation, or severely impaired renal function, and should be used with caution in patients with renal impairment, heart disease, IBD, patients on concomitant medications that affect electrolyte balance (eg, diuretics), and in elderly or debilitated patients (65).
Few data are available on the biochemical and hemodynamic effects of PSMC. In one study (55), PEG was associated with significant decreases in potassium levels, while PSMC was associated with significant decreases in chloride levels and significant increases in magnesium levels. In another study (47), there were no significant changes in hemoglobin, hematocrit, sodium, potassium, phosphate, calcium, urea or albumin levels with PSMC, compared with a significant increase in phosphate levels with $\mathrm{NaP}$ (47). However, significant dehydration and electrolyte abnormalities have been described (64). The 16 Australian adverse reports (64) implicating PSMC, described by the Adverse Drug Reactions Advisory Committee, included eight reports of adverse events (ie, convulsions, syncope, unconsciousness and metabolic alkalosis) associated with hyponatremia, as well as four reports of syncope and dehydration without documented electrolyte abnormalities. Electrolyte abnormalities resulting in seizures have been reported in a patient using PSMC (76).

Two studies $(87,88)$ have reported that PSMC was used safely and effectively in patients with IBD; however, neither study assessed the impact on histological results.

\section{Mg-citrate}

Mg-citrate is contraindicated in patients with abdominal pain or hemorrhage, intestinal obstruction or impaired renal function, and should be used with caution in patients on a low-sodium diet (65). The major route of Mg-citrate excretion is renal, and severe or even fatal episodes of hypermagnesemia have been reported in patients with suspected or known renal failure or elderly patients $(89,90)$. Electrolyte abnormalities resulting in seizures have been reported in a patient using PSMC (76).

\section{EFFICACY AND TOLERABILITY IN PEDIATRIC POPULATIONS}

Unlike studies in adults, there are very few studies actually evaluating and/or comparing the various methods used to prepare the colon for colonoscopy in infants or younger children. Most bowel preparation strategies are simply adapted from those used in adult patients; however, this may not always be appropriate. Compliance is often the first obstacle in children. The choice of preparation will be affected by the patient's age, taste of the medication, volume to be consumed and product formulation (pill versus liquid). Often children require admission to a day procedure unit and administration of the bowel cleansing preparation via a nasogastric (NG) tube. The data on safety and side effects in children are also limited.

PEG electrolyte solution was assessed in 20 children (1.5 to 19 years of age) and found to provide adequate colon cleansing, but $55 \%$ of children required an NG tube to take the solution (91). The majority of children had significant discomfort taking the solution. There were also minor changes in urine osmolality, urea, serum glucose and potassium levels. Two other studies $(92,93)$ comparing lavage solution with oral $\mathrm{NaP}$ in 63 children (three to 17 years of age) found that children tolerated the oral $\mathrm{NaP}$ better, but hyperphosphatemia occurred in both studies (Table 7). A prospective trial (94) reported 46 children (2.8 to 17.8 years of age) who were given PEG $2 \mathrm{~L}$ in a beverage, divided into two to three doses, for four days. Patients went from an average of 2.5 stools/day to six stools/day before colonoscopy. Overall the preparation was successful. There were no comments on the ability of children to go to school or to participate in activities, especially with five to six stools/day. No patients 


\section{TABLE 7}

Randomized comparisons of bowel preparations for colonoscopy in children

\begin{tabular}{|c|c|c|c|c|}
\hline Reference & n & Preparation & Efficacy & Tolerability and acceptability \\
\hline \multirow[t]{2}{*}{ Gremse et al (92) } & 34 & $\mathrm{NaP}$ & $\mathrm{NaP}>\mathrm{PEG}$ & $\mathrm{NaP}>\mathrm{PEG}$ \\
\hline & & PEG & & \\
\hline \multirow[t]{2}{*}{ da Silva et al (93) } & 29 & $\mathrm{NaP}$ & Not reported & $\mathrm{NaP}>\mathrm{PEG}$ \\
\hline & & PEG & & \\
\hline \multirow[t]{3}{*}{ Dahshan et al (95) } & 70 & PEG & PEG $>$ Mg-citrate $>$ bisacodyl + enema & Mg-citrate $=$ bisacodyl + enema $>$ PEG \\
\hline & & Mg-citrate & & \\
\hline & & Bisacodyl + enema & & \\
\hline \multirow[t]{2}{*}{ El-Baba et al (96) } & 62 & $\mathrm{NaP}$ & Mg-citrate + bisacodyl + diet kit $>\mathrm{NaP}$ & Mg-citrate + bisacodyl + diet kit $>\mathrm{NaP}$ \\
\hline & & Mg-citrate + bisacodyl + diet kit & & \\
\hline \multirow[t]{2}{*}{ Pinfield and Stringer (97) } & 66 & PSMC & PSMC > bisacodyl + enema & PSMC > bisacodyl + enema \\
\hline & & Bisacodyl + enema & & \\
\hline
\end{tabular}

Mg-citrate Magnesium citrate; NaP Sodium phosphate; PEG Polyethylene glycol; PSMC Sodium picosulphate plus Mg-citrate

appeared dehydrated but there were small but significant decreases in serum potassium, carbon dioxide and urea levels, although all still remained in the normal range with respect to age.

An RCT compared three combination bowel cleansing preparations in 77 children (three to 20 years of age): Mg-citrate and senna with clear liquid diet for two days; bisacodyl daily for two days; and PEG $(20 \mathrm{~mL} / \mathrm{kg})$ and clear liquid diet at home on the day before colonoscopy, and $\mathrm{NaP}$ enema the day of colonoscopy (95). The PEG preparation provided the best cleansing but was the least well-tolerated with the greatest incidence of reported side effects (vomiting and poor sleep). The bisacodyl preparation was the best tolerated but provided significantly worse bowel cleansing. Electrolyte levels and hydration status were not assessed.

In another trial ( $\mathrm{n}=62$, mean age 12.5 years), bisacodyl in combination with $\mathrm{Mg}$-citrate and a low-residue diet (prepackaged) was compared with two doses of $\mathrm{NaP}$ and a clear liquid diet administered the day before the procedure (96). Bowel cleansing was more effective with the combination of bisacodyl and Mg-citrate. Reported side effects were high in both groups ( $83 \%$ with bisacodyl and $100 \%$ with $\mathrm{NaP}$ ), but only examined complaints such as headache, bloating, sleep disturbance and anal irritation. Safety data were not gathered.

Three studies (97-99) have reported on the combination of an oral laxative and enemas. An RCT of 63 children (18 months to 16 years of age) compared PSMC and a clear liquid diet with a bisacodyl and $\mathrm{NaP}$ enema combination and an unrestricted diet up to $6 \mathrm{~h}$ before colonoscopy (97). The PSMC regimen included two doses adjusted for weight and age, one at $24 \mathrm{~h}$ pre-endoscopy and the second at $18 \mathrm{~h}$. One hundred per cent of patients from the PSMC group had a good or excellent preparation compared with $71 \%$ of patients from the bisacodyl and $\mathrm{NaP}$ enema combination group. An open study (98) evaluating oral bisacodyl for two days and a $\mathrm{NaP}$ enema in 30 children, reported excellent efficacy in $86 \%$ of children. No safety data were gathered. A second open study (99) compared various combinations of liquid diet, senna or Mg-citrate and one or two $\mathrm{NaP}$ enemas up to $48 \mathrm{~h}$ before the procedure. Although the authors thought that the preparations were adequate, the majority of children still had either liquid or semiformed stool at the time of the procedure. Again, no safety data were obtained.

All of the regimens have some downsides. In general, lavage solutions are effective if an adequate dose may be administered but are often not well tolerated and need to be given via an NG tube. Oral $\mathrm{NaP}$ solution causes increases in serum phosphate levels, as are seen in adults. Whether low-volume PEG mixed in multiple glasses of fluid (carbohydrate-electrolyte solution, eg, Pedialyte, Abbott Laboratories Ltd, Canada) may be given safely over a shorter time period, with similar results, remains to be seen. Results with PSMC look promising, but there are no safety data looking at either electrolyte or hydration issues. Given the lack of adequate data assessing both efficacy and safety, it is difficult to recommend any one regimen for adequate bowel preparation in children.

Similar to the process in adults, all regimens need to ensure adequate hydration, especially in younger patients. It is important to remember that although sports drinks may be used as a 'hydration drink' in adults undergoing colonoscopy preparation protocols, the salt to sugar ratio is not appropriate for younger children. A carbohydrate-electrolyte solution designed for pediatric populations, such as Pedialyte, may be useful. Parents should be given guidelines to follow to ensure children stay adequately hydrated during the preparation period, which hopefully may be contained within $24 \mathrm{~h}$. In addition, infants and children often become irritable and cry when placed on a clear fluid diet and/or a restricted diet. Parents have difficulty coping with this, and prolonging dietary restrictions while giving unpalatable medications may be near impossible to achieve. Further studies are needed to look at feasibility and efficacy, as well as safety, of various colonoscopy preparation protocols in children.

\section{ROLE OF BOWEL CLEANSING PREPARATIONS IN CAPSULE ENDOSCOPY}

In an effort to improve visibility of the distal small intestine in capsule endoscopy, several studies (100-106) have assessed PEG (in varying volumes), $\mathrm{NaP}$ and simethicone for bowel cleansing before the ingestion of the wireless device. Bowel preparation may change small bowel transit time (100-104) and visibility $(102,105,106)$, which may lead to a higher rate of complete capsule endoscopy studies (102) and a higher diagnostic yield (103). While bowel cleansing before capsule may be useful, its routine use, let alone what preparation to use, remains the subject of ongoing debate (107).

It has been suggested that $\mathrm{NaP}$ may not be the best choice because of its propensity to induce erosions (83-86). It is possible 


\section{TABLE 8}

The Canadian Association of Gastroenterology summary recommendations for bowel cleansing preparations

- Effective bowel preparations are critical to a high-quality colonoscopy examination and successful screening or surveillance programs of colonic pathology.

- All preparations can cause adverse events, including rare serious negative outcomes.

- NaP preparations appear more effective and better tolerated than standard PEG solutions.

- Regimens of PEG $2 \mathrm{~L}$ with bisacodyl (10 mg to $20 \mathrm{mg}$ ) or Mg-citrate $(296 \mathrm{~mL})$ are as effective as standard PEG $4 \mathrm{~L}$ regimens but are better tolerated and, therefore, may be the PEG regimens of choice.

- The efficacy of PSMC appears to be very good with excellent tolerability; head-to-head trials with $\mathrm{NaP}$ solutions are few and conclusions regarding comparative efficacy remain equivocal.

- Adequate hydration during preparation and up to the time of colonoscopy is critical to minimizing side effects in patients receiving NaP solutions, and probably PSMC preparations. Better hydration may also improve the quality of the bowel preparation.

- The Health Canada recommended dosing of $\mathrm{NaP}$ is $90 \mathrm{~mL}$ given as two $45 \mathrm{~mL}$ doses $24 \mathrm{~h}$ apart; however, in most clinical trials, the NaP dosing strategy was two $45 \mathrm{~mL}$ doses within $24 \mathrm{~h}$. Many members of our expert panel administer both doses within $24 \mathrm{~h}$, with one of the doses on the morning of the procedure, after careful one-on-one discussion of risks and benefits in carefully selected patients. Carbohydrate-electrolyte solutions may improve the efficacy and tolerability compared with $\mathrm{NaP}$ alone.

- The use of NaP preparations should be limited to patients without cardiac or renal dysfunction, bowel obstruction and ascites, and caution should be exercised when administering to patients with pre-existing electrolyte disturbances, patients taking medications that can affect electrolyte levels and elderly or debilitated patients.

- Safety data on PSMC and combination preparations in North America are limited and clinicians are encouraged to keep abreast of developments in this area.

- The Canadian Association of Gastroenterology urges its members, as always, to weigh the benefits and risks of the administration of any medications or compounds, including bowel cleansing preparations, on an individual basis.

Mg-citrate Magnesium citrate; NaP Sodium phosphate; PEG Polyethylene glycol; PSMC Sodium picosulphate plus Mg-citrate

that these erosions may be misinterpreted in a capsule study, but this has not yet been demonstrated in studies. The use of a cathartic resulting in an unpleasant preparation has the disadvantage of removing some of the simplicity of the capsule test which is viewed as a noninvasive, painless study by many people.

\section{CONCLUSIONS}

Effective bowel preparations are critical to a high-quality colonoscopy examination and successful screening or surveillance programs of colonic pathology. Table 8 lists the CAG recommendations relating to these preparations.

All preparations have been associated with adverse events, including lethal outcomes. Although $\mathrm{NaP}$ preparations appear more effective and better tolerated than PEG solutions, their use should be limited to patients without cardiac or renal dysfunction, and caution should be exercised when they are administered to patients with pre-existing electrolyte disturbances, patients using medications that result in electrolyte disturbances and elderly or debilitated patients. A recent advisory recommended the administration of the full $\mathrm{NaP}$ preparation over two days. Adequate hydration is critical to minimizing side effects in patients receiving NaP, and probably PSMC preparations. Additionally, adequate consumption of clear fluids is essential to maintain any remaining effluent in the bowel in a fluid state so that it may be readily suctioned. The efficacy of PSMC appears to be very good but comparative trials with $\mathrm{NaP}$ are lacking and the preliminary conclusions equivocal. It may be best tolerated when compared with $\mathrm{NaP}$ and PEG preparations. There are few data on Mg-citrate because it is rarely used alone in preparation for colonoscopy.

The CAG urges its members, as always, to weigh the benefits and risks of the administration of any medications or compounds, including bowel cleansers, on an individual basis, and to keep abreast of evolving literature in this important area.

The present position paper was endorsed and organized by the Canadian Association of Gastroenterology.

ACKNOWLEDGEMENTS: The Canadian Association of Gastroenterology thanks AstraZeneca Pharma Inc; Ferring Pharmaceuticals Inc; Janssen-Ortho Inc; McNeil Consumer Healthcare and Rivex Pharma Inc for their unrestricted grants in support of the development of the present position paper.

DISCLOSURES: Dr Chiba and Dr Enns have received consulting fees and participated in a speaker's bureau for Janssen-Ortho Inc. Dr Chiba has also received clinical trial funding from Janssen-Ortho Inc.

\section{REFERENCES}

1. National Cancer Institute of Canada. Canadian cancer statistics 2006. $<$ http://www.ncic.cancer.ca/vgn/images/portal/cit_86751114/31/23/ 935505938cw_2006stats_en.pdf.pdf > (Version current at October 17, 2006).

2. Lieberman DA, Holub J, Eisen G, Kraemer D, Morris CD. Utilization of colonoscopy in the United States: Results from a national consortium. Gastrointest Endosc 2005;62:875-83.

3. Huang EH, Marks JM. The diagnostic and therapeutic roles of colonoscopy: A review. Surg Endosc 2001;15:1373-80.

4. Harewood GC, Sharma VK, de Garmo P. Impact of colonoscopy preparation quality on detection of suspected colonic neoplasia. Gastrointest Endosc 2003;58:76-9.

5. Aslinia F, Uradomo L, Steele A, Greenwald BD, Raufman JP. Quality assessment of colonoscopic cecal intubation: An analysis of 6 years of continuous practice at a university hospital. Am J Gastroenterol 2006;101:721-31.

6. Froehlich F, Wietlisbach V, Gonvers JJ, Burnand B, Vader JP. Impact of colonic cleansing on quality and diagnostic yield of colonoscopy: The European Panel of Appropriateness of Gastrointestinal Endoscopy European multicenter study. Gastrointest Endosc 2005;61:378-84.

7. Rex DK, Imperiale TF, Latinovich DR, Bratcher LL. Impact of bowel preparation on efficiency and cost of colonoscopy. Am J Gastroenterol 2002;97:1696-700.

8. Hsu CW, Imperiale TF. Meta-analysis and cost comparison of polyethylene glycol lavage versus sodium phosphate for colonoscopy preparation. Gastrointest Endosc 1998;48:276-82.

9. Harewood GC, Wiersema MJ, Melton LJ III. A prospective, controlled assessment of factors influencing acceptance of screening colonoscopy. Am J Gastroenterol 2002;97:3186-94.

10. Wexner SD, Beck DE, Baron TH, et al. A consensus document on bowel preparation before colonoscopy: Prepared by a task force from the American Society of Colon and Rectal Surgeons (ASCRS), the American Society for Gastrointestinal Endoscopy (ASGE), and the 
Society of American Gastrointestinal and Endoscopic Surgeons (SAGES). Dis Colon Rectum 2006;49:792-809.

11. Regev A, Fraser G, Delpre G, et al. Comparison of two bowel preparations for colonoscopy: Sodium picosulphate with magnesium citrate versus sulphate-free polyethylene glycol lavage solution. Am J Gastroenterol 1998;93:1478-82.

12. DiPalma JA, Brady CE III, Stewart DL, et al. Comparison of colon cleansing methods in preparation for colonoscopy. Gastroenterology 1984;86:856-60.

13. Thomas G, Brozinsky S, Isenberg JI. Patient acceptance and effectiveness of a balanced lavage solution (Golytely) versus the standard preparation for colonoscopy. Gastroenterology 1982;82:435-7.

14. Vanner SJ, MacDonald PH, Paterson WG, Prentice RS, Da Costa LR, Beck IT. A randomized prospective trial comparing oral sodium phosphate with standard polyethylene glycol-based lavage solution (Golytely) in the preparation of patients for colonoscopy. Am J Gastroenterol 1990;85:422-7.

15. Kolts BE, Lyles WE, Achem SR, Burton L, Geller AJ, MacMath T. A comparison of the effectiveness and patient tolerance of oral sodium phosphate, castor oil, and standard electrolyte lavage for colonoscopy or sigmoidoscopy preparation. Am J Gastroenterol 1993;88:1218-23.

16. Marshall JB, Pineda JJ, Barthel JS, King PD. Prospective, randomized trial comparing sodium phosphate solution with polyethylene glycol-electrolyte lavage for colonoscopy preparation. Gastrointest Endosc 1993;39:631-4.

17. Cohen SM, Wexner SD, Binderow SR, et al. Prospective, randomized, endoscopic-blinded trial comparing precolonoscopy bowel cleansing methods. Dis Colon Rectum 1994;37:689-96.

18. Golub RW, Kerner BA, Wise WE Jr, et al. Colonoscopic bowel preparations - which one? A blinded, prospective, randomized trial. Dis Colon Rectum 1995;38:594-9.

19. Henderson JM, Barnett JL, Turgeon DK, et al. Single-day, divided-dose oral sodium phosphate laxative versus intestinal lavage as preparation for colonoscopy: Efficacy and patient tolerance. Gastrointest Endosc 1995;42:238-43.

20. Thomson A, Naidoo P, Crotty B. Bowel preparation for colonoscopy: A randomized prospective trial comparing sodium phosphate and polyethylene glycol in a predominantly elderly population. J Gastroenterol Hepatol 1996;11:103-7.

21. Clarkston WK, Tsen TN, Dies DF, Schratz CL, Vaswani SK, Bjerregaard P. Oral sodium phosphate versus sulfate-free polyethylene glycol electrolyte lavage solution in outpatient preparation for colonoscopy: A prospective comparison. Gastrointest Endosc 1996;43:42-8.

22. Frommer D. Cleansing ability and tolerance of three bowel preparations for colonoscopy. Dis Colon Rectum 1997;40:100-4.

23. Lee J, McCallion K, Acheson AG, Irwin ST. A prospective randomised study comparing polyethylene glycol and sodium phosphate bowel cleansing solutions for colonoscopy. Ulster Med J 1999;68:68-72.

24. Arezzo A. Prospective randomized trial comparing bowel cleaning preparations for colonoscopy. Surg Laparosc Endosc Percutan Tech 2000;10:215-7.

25. Kastenberg D, Chasen R, Choudhary C, et al. Efficacy and safety of sodium phosphate tablets compared with PEG solution in colon cleansing: Two identically designed, randomized, controlled, parallel group, multicenter phase III trials. Gastrointest Endosc 2001;54:705-13.

26. Law WL, Choi HK, Chu KW, Ho JW, Wong L. Bowel preparation for colonoscopy: A randomized controlled trial comparing polyethylene glycol solution, one dose and two doses of oral sodium phosphate solution. Asian J Surg 2004:27:120-4.

27. Seinela L, Pehkonen E, Laasanen T, Ahvenainen J. Bowel preparation for colonoscopy in very old patients: A randomized prospective trial comparing oral sodium phosphate and polyethylene glycol electrolyte lavage solution. Scand J Gastroenterol 2003;38:216-20.

28. Hwang KL, Chen WT, Hsiao KH, et al. Prospective randomized comparison of oral sodium phosphate and polyethylene glycol lavage for colonoscopy preparation. World J Gastroenterol 2005;11:7486-93.

29. Ell C, Fischbach W, Keller R, et al; Hintertux Study Group. A randomized, blinded, prospective trial to compare the safety and efficacy of three bowel-cleansing solutions for colonoscopy (HSG-01*). Endoscopy 2003;35:300-4.
30. Hookey LC, Depew WT, Vanner SJ. A prospective randomized trial comparing low-dose oral sodium phosphate plus stimulant laxatives with large volume polyethylene glycol solution for colon cleansing. Am J Gastroenterol 2004;99:2217-22.

31. Young CJ, Simpson RR, King DW, Lubowski DZ. Oral sodium phosphate solution is a superior colonoscopy preparation to polyethylene glycol with bisacodyl. Dis Colon Rectum 2000;43:1568-71.

32. Chilton AP, O'Sullivan M, Cox MA, Loft DE, Nwokolo CU. A blinded, randomized comparison of a novel, low-dose, triple regimen with fleet phospho-soda: A study of colon cleanliness, speed and success of colonoscopy. Endoscopy 2000;32:37-41.

33. Wang HS, Lin JK. A randomized prospective trial of bowel preparation for colonoscopy with Fortrans compared with bisacodyl. J Chin Med Assoc 2003;66:364-9.

34. Radaelli F, Meucci G, Imperiali G, et al. High-dose senna compared with conventional PEG-ES lavage as bowel preparation for elective colonoscopy: A prospective, randomized, investigator-blinded trial. Am J Gastroenterol 2005;100:2674-80.

35. Clarkston WK, Smith OJ. The use of GoLYTELY and Dulcolax in combination in outpatient colonoscopy. J Clin Gastroenterol 1993;17:146-8.

36. Ziegenhagen DJ, Zehnter E, Tacke W, Kruis W. Addition of senna improves colonoscopy preparation with lavage: A prospective randomized trial. Gastrointest Endosc 1991;37:547-9.

37. Sharma VK, Steinberg EN, Vasudeva R, Howden CW. Randomized, controlled study of pretreatment with magnesium citrate on the quality of colonoscopy preparation with polyethylene glycol electrolyte lavage solution. Gastrointest Endosc 1997;46:541-3.

38. Hookey LC, Depew WT, Vanner SJ. Combined low volume polyethylene glycol solution plus stimulant laxatives versus standard volume polyethylene glycol solution: A prospective, randomized study of colon cleansing before colonoscopy. Can J Gastroenterol 2006;20:101-5.

39. Sharma VK, Chockalingham SK, Ugheoke EA, et al. Prospective, randomized, controlled comparison of the use of polyethylene glycol electrolyte lavage solution in four-liter versus two-liter volumes and pretreatment with either magnesium citrate or bisacodyl for colonoscopy preparation. Gastrointest Endosc 1998;47:167-71.

40. Adams WJ, Meagher AP, Lubowski DZ, King DW. Bisacodyl reduces the volume of polyethylene glycol solution required for bowel preparation. Dis Colon Rectum 1994;37:229-33; discussion 233-4.

41. DiPalma JA, Wolff BG, Meagher A, Cleveland M. Comparison of reduced volume versus four liters sulfate-free electrolyte lavage solutions for colonoscopy colon cleansing. Am J Gastroenterol 2003;98:2187-91.

42. Huppertz-Hauss G, Bretthauer M, Sauar J, et al. Polyethylene glycol versus sodium phosphate in bowel cleansing for colonoscopy: A randomized trial. Endoscopy 2005;37:537-41.

43. Hangartner PJ, Munch R, Meier J, Ammann R, Buhler H. Comparison of three colon cleansing methods: Evaluation of a randomized clinical trial with 300 ambulatory patients. Endoscopy 1989;21:272-5.

44. Borkje B, Pedersen R, Lund GM, Enehaug JS, Berstad A. Effectiveness and acceptability of three bowel cleansing regimens. Scand J Gastroenterol 1991;26:162-6.

45. Aoun E, Abdul-Baki H, Azar C, et al. A randomized single-blind trial of split-dose PEG-electrolyte solution without dietary restriction compared with whole dose PEG-electrolyte solution with dietary restriction for colonoscopy preparation. Gastrointest Endosc 2005;62:213-8.

46. El Sayed AM, Kanafani ZA, Mourad FH, et al. A randomized single-blind trial of whole versus split-dose polyethylene glycol-electrolyte solution for colonoscopy preparation. Gastrointest Endosc 2003;58:36-40.

47. Yoshioka K, Connolly AB, Ogunbiyi OA, et al. Randomized trial of oral sodium phosphate compared with oral sodium picosulphate (Picolax) for elective colorectal surgery and colonoscopy. Dig Surg 2000;17:66-70.

48. Tjandra JJ, Chan M, Tagkalidis PP. Oral sodium phosphate (Fleet) is a superior colonoscopy preparation to Picopre (sodium picosulfate-based preparation). Dis Colon Rectum 2006;49:616-20.

49. Schmidt LM, Williams P, King D, Perera D. Picoprep-3 is a superior colonoscopy preparation to Fleet: A randomized, controlled trial comparing the two bowel preparations. Dis Colon Rectum 2004;47:238-42. 
50. Afridi SA, Barthel JS, King PD, Pineda JJ, Marshall JB. Prospective, randomized trial comparing a new sodium phosphate-bisacodyl regimen with conventional PEG-ES lavage for outpatient colonoscopy preparation. Gastrointest Endosc 1995;41:485-9.

51. Barclay RL, Depew WT, Vanner SJ. Carbohydrate-electrolyte rehydration protects against intravascular volume contraction during colonic cleansing with orally administered sodium phosphate. Gastrointest Endosc 2002;56:633-8.

52. Tjandra JJ, Tagkalidis P. Carbohydrate-electrolyte (E-Lyte) solution enhances bowel preparation with oral fleet phospho-soda. Dis Colon Rectum 2004:47:1181-6.

53. Scott SR, Raymond PL, Thompson WO, Galt DJ. Efficacy and tolerance of sodium phosphates oral solution after diet liberalization. Gastroenterol Nurs 2005;28:133-9.

54. Dakkak M, Aziz K, Bennett JR. Short report: Comparison of two orally administered bowel preparations for colonoscopy polyethylene glycol and sodium picosulphate. Aliment Pharmacol Ther 1992;6:513-9.

55. Hamilton D, Mulcahy D, Walsh D, Farrelly C, Tormey WP, Watson G. Sodium picosulphate compared with polyethylene glycol solution for large bowel lavage: A prospective randomised trial. Br J Clin Pract 1996;50:73-5.

56. Chen CC, Ng WW, Chang FY, Lee SD. Magnesium citrate-bisacodyl regimen proves better than castor oil for colonoscopic preparation. J Gastroenterol Hepatol 1999;14:1219-22.

57. Berkelhammer C, Ekambaram A, Silva RG. Low-volume oral colonoscopy bowel preparation: Sodium phosphate and magnesium citrate. Gastrointest Endosc 2002;56:89-94. (Erratum in 2002;56:612)

58. Delegge M, Kaplan R. Efficacy of bowel preparation with the use of a prepackaged, low fibre diet with a low sodium, magnesium citrate cathartic vs a clear liquid diet with a standard sodium phosphate cathartic. Aliment Pharmacol Ther 2005;21:1491-5.

59. Hookey LC, Depew WT, Vanner S. The safety profile of oral sodium phosphate for colonic cleansing before colonoscopy in adults. Gastrointest Endosc 2002;56:895-902.

60. Health Canada. Canadian Adverse Drug Reaction Monitoring Program (CADRMP) Adverse Reaction Database. $<$ http://www.hc-sc.gc.ca/dhp-mps/medeff/databasdon/agreement_ accord e.html> (Version current at October 17, 2006).

61. Maher M, Macdonald L. Canadian Adverse Reaction Newsletter. Oral sodium phosphates solutions: Electrolyte disturbances. $<$ http://www.hc-sc.gc.ca/dhp-mps/medeff/bulletin/carn-bcei_v12n2 e.html\#sodium_phosphates> (Version current at October 17, 2006).

62. Love J. The appropriate use of sodium phosphates oral solutions. Can J Gastroenterol 2003;17:531.

63. Periodic safety update report for Picolax, Ferring Pharmaceuticals Ltd (UK), Report\# FPL/Picolax/2/2001, May 21, 2001.

64. ADRAC. Electrolyte disturbances with sodium picosulfate bowel cleansing products. Aust Advers Drug React Bull 2002;21:1.

65. Canadian Pharmacists Association. Compendium of Pharmaceuticals and Specialties. Toronto: Webcom Ltd, 2005.

66. Marschall HU, Bartels F. Life-threatening complications of nasogastric administration of polyethylene glycol-electrolyte solutions (Golytely) for bowel cleansing. Gastrointest Endosc 1998:47:408-10.

67. Tooson JD, Gates LK Jr. Bowel preparation before colonoscopy. Choosing the best lavage regimen. Postgrad Med 1996;100:203-4, 207-12,214

68. Gabel A, Muller S. Aspiration: A possible severe complication in colonoscopy preparation of elderly people by orthograde intestine lavage. Digestion 1999;60:284-5.

69. Franga DL, Harris JA. Polyethylene glycol-induced pancreatitis. Gastrointest Endosc 2000;52:789-91.

70. Schroppel B, Segerer S, Keuneke C, Cohen CD, Schlondorff D. Hyponatremic encephalopathy after preparation for colonoscopy. Gastrointest Endosc 2001;53:527-9.

71. Turnage RH, Guice KS, Gannon P, Gross M. The effect of polyethylene glycol gavage on plasma volume. J Surg Res 1994;57:284-8.

72. Granberry MC, White LM, Gardner SF. Exacerbation of congestive heart failure after administration of polyethylene glycol-electrolyte lavage solution. Ann Pharmacother 1995;29:1232-5.

73. Ayus JC, Levine R, Arieff AI. Fatal dysnatraemia caused by elective colonoscopy. BMJ 2003;326:382-4.

74. Pockros PJ, Foroozan P. Golytely lavage versus a standard colonoscopy preparation. Effect on normal colonic mucosal histology. Gastroenterology 1985;88:545-8.
75. Holte K, Nielsen KG, Madsen JL, Kehlet H. Physiologic effects of bowel preparation. Dis Colon Rectum 2004;47:1397-402.

76. Frizelle FA, Colls BM. Hyponatremia and seizures after bowel preparation: Report of three cases. Dis Colon Rectum 2005:48:393-6.

77. Huynh T, Vanner S, Paterson W. Safety profile of 5-h oral sodium phosphate regimen for colonoscopy cleansing: Lack of clinically significant hypocalcemia or hypovolemia. Am J Gastroenterol 1995;90:104-7.

78. Health Canada. Health Canada Endorsed Important Safety Information on Fleet Phospho-Soda (Sodium Phosphates Oral Solution). <http://www.hc-sc.gc.ca/dhp-mps/medeff/ advisories-avis/prof/2005/phosphate_solutions_3_hpc-cps_e.html > (Version current at October 17, 2006).

79. Desmeules S, Bergeron MJ, Isenring P. Acute phosphate nephropathy and renal failure. N Engl J Med 2003;349:1006-7. (Lett)

80. Markowitz GS, Nasr SH, Klein P, et al. Renal failure due to acute nephrocalcinosis following oral sodium phosphate bowel cleansing. Hum Pathol 2004;35:675-84.

81. Markowitz GS, Stokes MB, Radhakrishnan J, D’Agati VD. Acute phosphate nephropathy following oral sodium phosphate bowel purgative: An underrecognized cause of chronic renal failure. J Am Soc Nephrol 2005;16:3389-96.

82. Abaskharoun R, Arunasalam K, Depew W, Vanner S. Oral sodium phosphate before colonoscopy does not predict the development of chronic renal failure. Can J Gastroenterol 2006;20(Suppl A):104A. (Abst)

83. Rejchrt S, Bures J, Siroky M, Kopacova M, Slezak L, Langr F. A prospective, observational study of colonic mucosal abnormalities associated with orally administered sodium phosphate for colon cleansing before colonoscopy. Gastrointest Endosc 2004;59:651-4.

84. Wong NA, Penman ID, Campbell S, Lessells AM. Microscopic focal cryptitis associated with sodium phosphate bowel preparation. Histopathology 2000;36:476-8.

85. Hixson LJ. Colorectal ulcers associated with sodium phosphate catharsis. Gastrointest Endosc 1995;42:101-2.

86. Zwas FR, Cirillo NW, el-Serag HB, Eisen RN. Colonic mucosal abnormalities associated with oral sodium phosphate solution. Gastrointest Endosc 1996;43:463-6.

87. McDonagh AJ, Singh P, Pilbrow WJ, Youngs GR. Safety of Picolax (sodium picosulphate-magnesium citrate) in inflammatory bowel disease. BMJ 1989;299:776-7.

88. Evans M, Walker-Smith J, Williams C. Safety of Picolax in inflammatory bowel disease. BMJ 1989;299:1101-2.

89. Kontani M, Hara A, Ohta S, Ikeda T. Hypermagnesemia induced by massive cathartic ingestion in an elderly woman without pre-existing renal dysfunction. Intern Med 2005;44:448-52.

90. Schelling JR. Fatal hypermagnesemia. Clin Nephrol 2000;53:61-5.

91. Sondheimer JM, Sokol RJ, Taylor SF, Silverman A, Zelasney B. Safety, efficacy, and tolerance of intestinal lavage in pediatric patients undergoing diagnostic colonoscopy. J Pediatr 1991;119:148-52.

92. Gremse DA, Sacks AI, Raines S. Comparison of oral sodium phosphate to polyethylene glycol-based solution for bowel preparation for colonoscopy in children. J Pediatr Gastroenterol Nutr 1996;23:586-90.

93. da Silva MM, Briars GL, Patrick MK, Cleghorn GJ, Shepherd RW. Colonoscopy preparation in children: Safety, efficacy, and tolerance of high- versus low-volume cleansing methods. J Pediatr Gastroenterol Nutr 1997;24:33-7.

94. Pashankar DS, Uc A, Bishop WP. Polyethylene glycol 3350 without electrolytes: A new safe, effective, and palatable bowel preparation for colonoscopy in children. J Pediatr 2004;144:358-62.

95. Dahshan A, Lin CH, Peters J, Thomas R, Tolia V. A randomized, prospective study to evaluate the efficacy and acceptance of three bowel preparations for colonoscopy in children. Am J Gastroenterol 1999;94:3497-501.

96. El-Baba MF, Padilla M, Houston C, et al. A prospective study comparing oral sodium phosphate solution to a bowel cleansing preparation with nutrition food package in children. J Pediatr Gastroenterol Nutr 2006;42:174-7.

97. Pinfield A, Stringer MD. Randomised trial of two pharmacological methods of bowel preparation for day case colonoscopy. Arch Dis Child 1999;80:181-3.

98. Abubakar K, Goggin N, Gormally S, Durnin M, Drumm B. Preparing the bowel for colonoscopy. Arch Dis Child 1995;73:459-61. 
99. Trautwein AL, Vinitski LA, Peck SN. Bowel preparation before colonoscopy in the pediatric patient: A randomized study. Gastroenterol Nurs 1996;19:137-9.

100. Fireman Z, Paz D, Kopelman Y. Capsule endoscopy: Improving transit time and image view. World J Gastroenterol 2005;11:5863-6.

101. Ben-Soussan E, Savoye G, Antonietti M, Ramirez S, Ducrotte P, Lerebours E. Is a 2-liter PEG preparation useful before capsule endoscopy? J Clin Gastroenterol 2005;39:381-4.

102. Dai N, Gubler C, Hengstler P, Meyenberger C, Bauerfeind P. Improved capsule endoscopy after bowel preparation. Gastrointest Endosc 2005;61:28-31.

103. Viazis N, Sgouros S, Papaxoinis K, et al. Bowel preparation increases the diagnostic yield of capsule endoscopy: A prospective, randomized, controlled study. Gastrointest Endosc 2004;60:534-8.
104. Fireman Z, Kopelman Y, Fish L, Sternberg A, Scapa E, Mahaina E. Effect of oral purgatives on gastric and small bowel transit time in capsule endoscopy. Isr Med Assoc J 2004;6:521-3.

105. Albert J, Gobel CM, Lesske J, Lotterer E, Nietsch H, Fleig WE. Simethicone for small bowel preparation for capsule endoscopy: A systematic, single-blinded, controlled study. Gastrointest Endosc 2004;59:487-91.

106. Niv Y, Niv G, Wiser K, Demarco DC. Capsule endoscopy Comparison of two strategies of bowel preparation. Aliment Pharmacol Ther 2005;22:957-62.

107. de Franchis R, Avgerinos A, Barkin J, Cave D, Filoche B; ICCE. ICCE consensus for bowel preparation and prokinetics. Endoscopy 2005;37:1040-5. 


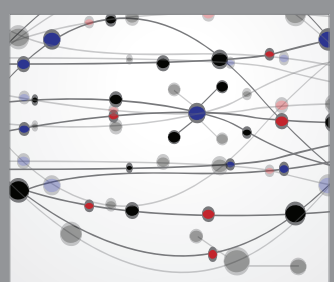

The Scientific World Journal
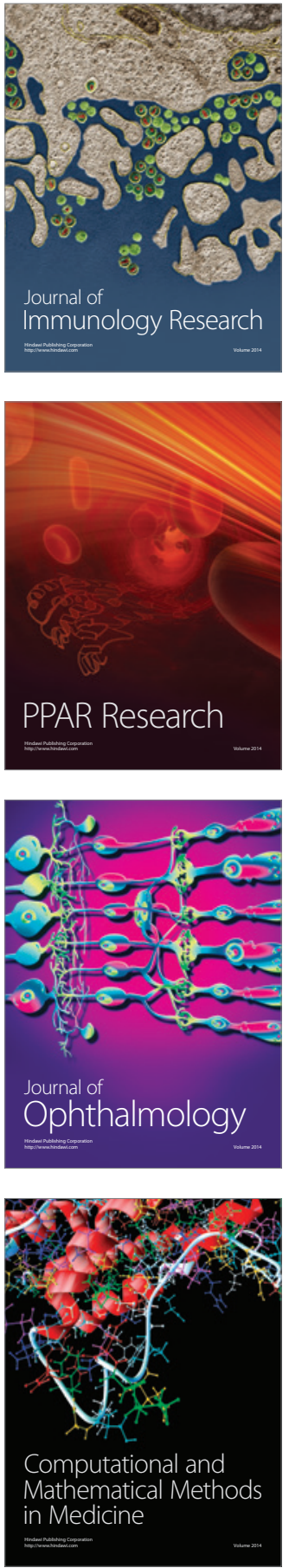

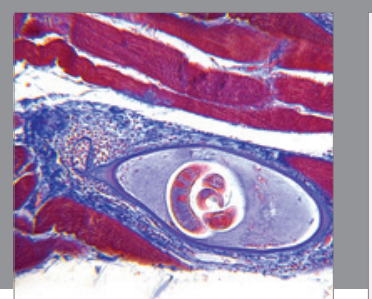

Gastroenterology Research and Practice

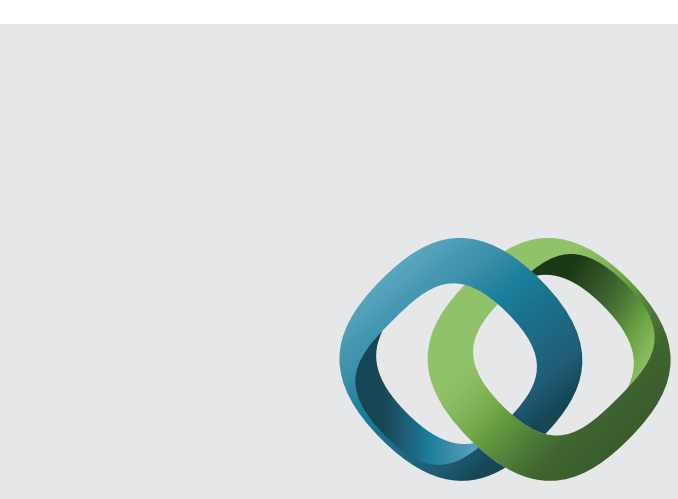

\section{Hindawi}

Submit your manuscripts at

http://www.hindawi.com
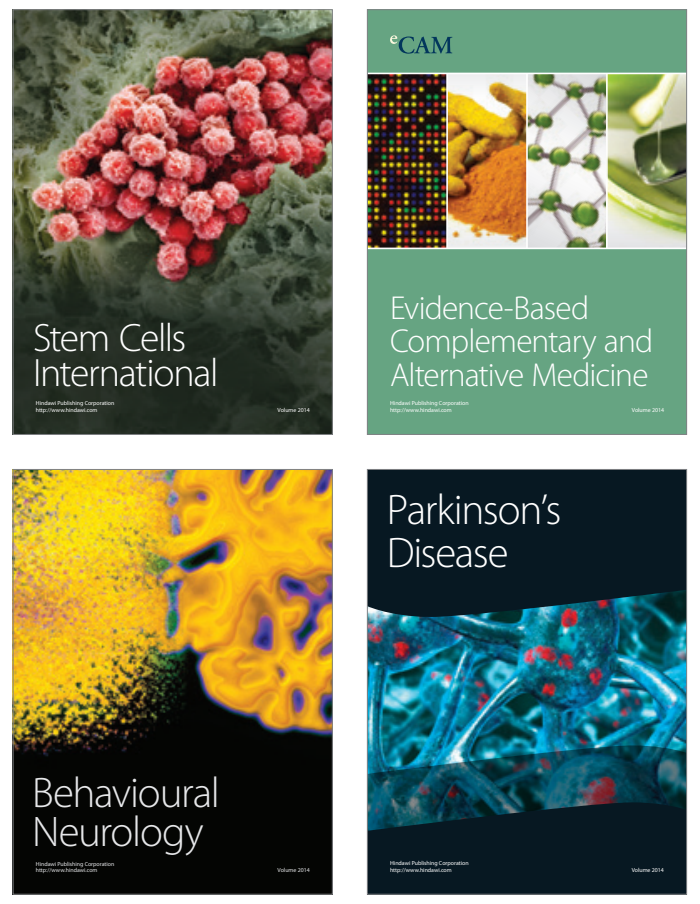
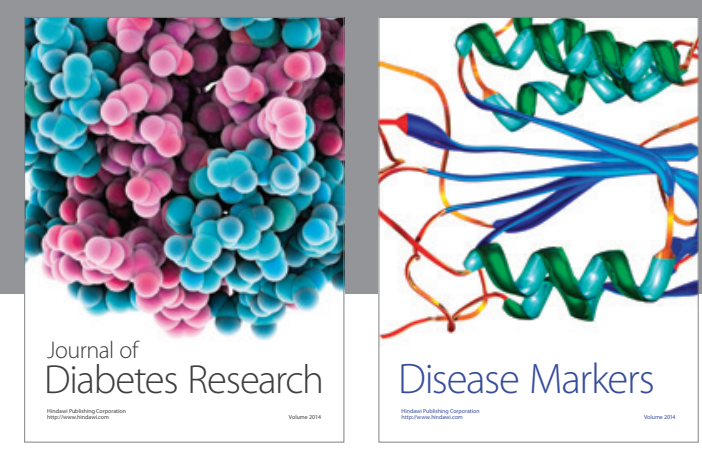

Disease Markers
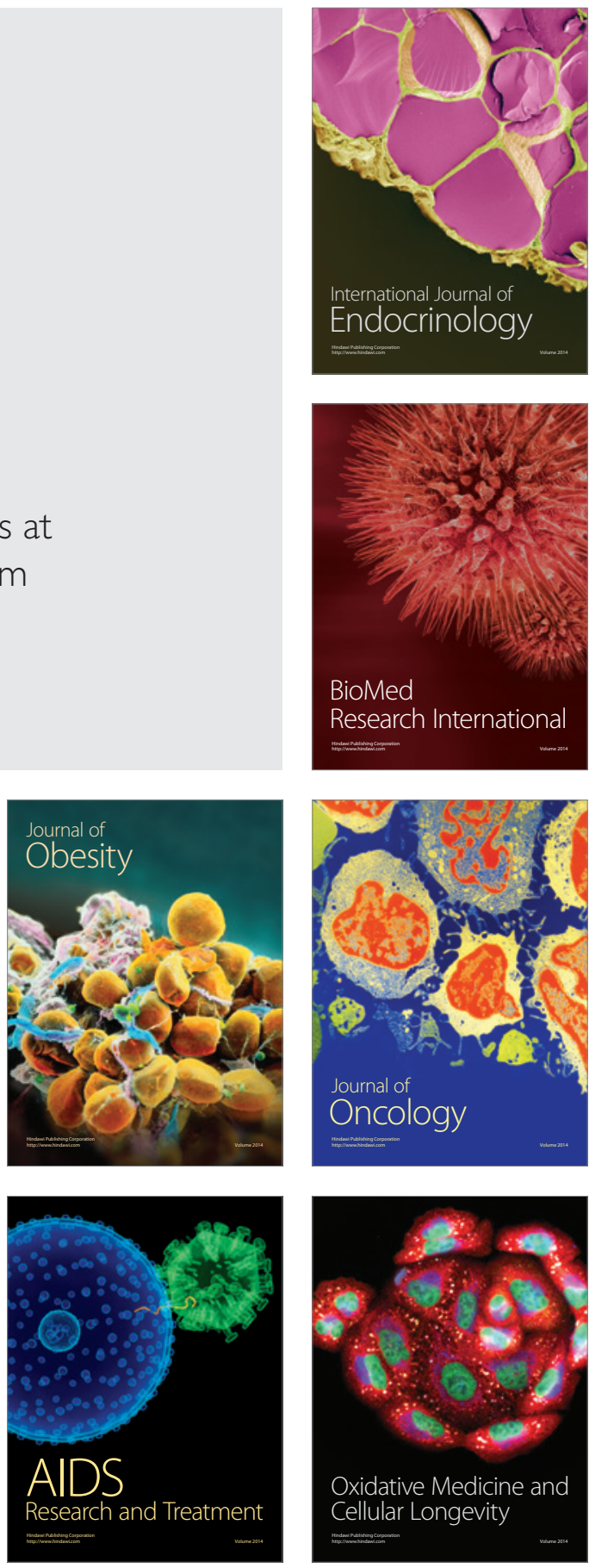